\title{
Internationalizing Teacher Education: One University's Journey From Awareness To Action
}

\author{
C. Bobbi Hansen, University of San Diego, USA
}

\begin{abstract}
In the 21 st century, it is more important than ever to include global/international education as an essential component of teacher education programs. This paper showcases one Department of Education's journey to internationalize its teacher credential program. Components of the reform include: 1) shared conversations, 2) goal-setting, 3) grant writing, 4) forming a learning community, 5) revising syllabi, and 6) surveying our graduates.
\end{abstract}

Keywords: Global/International Education; Teacher Education Reform

\section{INTRODUCTION}

I am not an Athenian or a Greek, but a citizen of the world. (Socrates)

lmost daily, various news sources make pronouncements that our schools are failing to meet the
needs of our students. If the basics of the $3 \mathrm{Rs}$ are not enough to cause concern, there now exists a
keen interest in what knowledge and skills students will need to succeed in the $21^{\text {st }}$ Century. Sweeping legislation in the US has garnered recent media attention with the new Common Core State Standards (CCSS), a U.S. education initiative, sponsored by the National Governors Association (NGA) and the Council of Chief State School Officers (CCSSO) that seeks to bring diverse state standards into alignment with each other while educating students for career and college readiness (Author, 2010). Additionally, groups, both in and out of education, have worked to conceptualize new educational reform models for teaching students in the $21^{\text {st }}$ century. The Partnership for 21st Century Skills (P21), an organization that brings together a diverse group of stake-holders that of educators, business individuals, and policymakers - created a powerful vision for 21st century education. That vision includes students becoming skilled in critical thinking, communication, creativity and collaboration, also known as the "4 Cs". However, P21 also recognized what scholars had been saying for years - that students desperately needed a better understanding of a world that is increasingly interconnected (Gragert, 2009; Gutek, 1993; Biddle, 1996; Diaz, Massialas, and Xanthopoulos, 1999; Calleja, 1995; Fuller, 1998). Global awareness, defined in the P21 document, includes: 1) using 21st century skills to understand and address global issues, 2) learning from and working collaboratively with individuals representing diverse cultures, religions and lifestyles in a spirit of mutual respect and open dialogue in personal, work and community contexts, and 3) understanding other nations and cultures. This paper examines the journey one US School of Education embarked upon to meet this $21^{\text {st }}$ century goal of producing globally competent teachers.

\section{THEORETICAL FRAMEWORK}

\section{The Need for Global Education}

Global education is not a new trend in the US. As far back as the 1960s and 1970s, the US had been involved in reforms calling for the adding of global education to the curriculum (Anderson, 1968; Hanvey, 1976; Becker, 1979). Then, however, the global education movement was more multicultural in nature with the goal of having students better understand peoples of all cultures in the US. Tye focused attention on global education for 
years and shared the following description: "Global education involves learning to understand and appreciate our neighbors who have different cultural background from ours - to see the world through the eyes and minds of others." (1991).

In the first decade of the 21st century, global education became more focused on international understanding (Adams \& Carfagna, 2006; Burbules \& Torres, 2000; Davies, 2006; Noddings, 2005). Merryfield, Lo, Po, and Kasai (2008) engaged in extensive research conducted over five years and created a framework for schools. This framework promoted the building of world-mindedness and asks schools to embrace five essential elements for student instruction: 1) knowledge of global interconnectedness, 2) inquiry into global issues, 3) skills in perspective consciousness, 4) open-mindedness (as recognition of bias, stereotypes, and exotica), and 5) intercultural experience and competence.

\section{From Global Education to International Education}

Friedman (2005) coined a term that became an instantly recognizable catch phrase and soon everyone was talking and writing about the "flat world". US educators took notice and began to heed warnings about the plight that US workers faced competing in a world marketplace. Even before Friedman, Skelton (2004) issued this strong message to educators: "If schools are to help their students develop international mindedness, then they need to take it just as seriously as they take the teaching and learning of mathematics..." (p.1). Others, speaking on the need for global education believe that educators must make international education central to the curriculum (Shorr, 2006; Darling-Hammond, 2010, Merryfield, 2002). Gragert's (2009) quote sums up this sentiment: "Educational reform that encompasses the infusion of global education into the K-12 education system is vital to the health and success of the 21st century global community" (p.1).

\section{Teacher Education Reform and Internationalization}

The importance of having students better understand the world must begin with teachers. Over the years efforts have been made in the US to include international education as a component in the curriculum at institutions for teacher education. Hanvey's (1982) guide to the internationalization of the curriculum was a critical point in international education and emerged from the teacher renewal movement at that time. This reform movement began to get the attention of administrators and faculty in schools of education. The American Association of Colleges of Teacher Education (AACTE) has spelled out what it means to internationalize the curriculum. Metzler (1998) noted that even though there is a renewed interest in K-12 global education programs, "it is disturbing and surprising that there have been limited attempts and fewer successes in internationalizing teacher education programs" (pg. 124).

\section{THE JOURNEY OF ONE TEACHER EDUCATION DEPARTMENT}

\section{Important Conversations}

This paper examined the process that one US School of Education embarked upon to meet this $21^{\text {st }}$ century goal of including international education as a component in the curriculum. Because of the global and political environment in recent years, no one in education could possibly be ignorant of the need to educate globally competent teachers. As the first step on this journey, we began to have informal conversations regarding the need to have our graduates acquire the skills and dispositions to promote world-minded citizens in their future classrooms. These conversations became more formalized as they became an integral component of our departmental meetings and were supported by administrators as part of our School's strategic plan that included the "development of highly effective, socially responsible, and marketable students through International Programs." A few of the faculty comments are:

I would like to see discussion of a theoretical foundation for internationalization: the power of being the other.

The purpose of internationalization is for students to think more deeply about themselves, the world they are citizens of, and their work on behalf of students. 
I envision that we will have a program that will be holistic in the sense that it operates as a theoretical framework.

I desire that we will have a place for formative and long-term monitoring of students' learning and its impact on their future work as teachers.

\section{Shared Goals}

From these open conversations, goals were formed. Because of our commitment to hearing all points of view, the negotiation and the creation of the final draft of the goals took quite awhile to complete. The goals we agree upon were: 1) to prepare teacher education candidates who demonstrate global awareness and cultural competency and incorporate their knowledge and skills into their teaching practice, 2) to support teacher candidates in developing knowledge of the international dimensions of the content areas, 3) to prepare teacher candidates with the pedagogical skills to develop K-12 students' global awareness, understanding, and ability to thoughtfully engage in international discourse within subject-specific disciplines, and 4) to research, document and disseminate the findings as to what constitutes quality global teaching programs by SOLES teacher credential faculty based on the research on international teacher education.

\section{Becoming a Learning Community}

In order to actualize the goals we developed, we knew we needed to become learners ourselves. For the next two years, we moved forward as a learning community. Recognizing that additional funding would greatly assist us in this endeavor, we wrote and were awarded two grants from The Longview Foundation for Education in World Affairs and International Understanding. The Longview Foundation supports agencies that promote international education for youth and programs and research that provide strategies for teachers to integrate global perspectives into their curriculum. The first grant, in 2007, supported faculty in integrating global knowledge and perspectives into their courses resulting in expanded learning outcomes/assignments for all students in foundations and methods classes. The newer grant, in 2009, supported our teacher candidates in developing knowledge of the international dimensions of their content areas and preparing them with the pedagogical skills to develop K-12 students' global awareness, understanding, and ability to thoughtfully engage in international discourse within subject-specific disciplines.

Additionally, the grants allowed us the resources with which to invite individuals to our campus whose expertise on international and global teacher education helped move us forward. Among these professionals were:

- $\quad$ Marry Merryfield, a faculty member from Ohio State University, presented a lecture on Integration of Technology to Support Teaching about World Cultures and also worked with small groups of faculty in a mentoring role.

- $\quad$ Yong Zhao, a faculty member from Michigan State University, lectured on Leading Schools in a Flat World: Globalization and its Implications for Education.

- Allan Luke, faculty member at Brisbane University-Australia, lectured on issues of quality, equity, language and culture.

- $\quad$ Steve Dudenhoefer, founder of AK' Tenamit educational program in Guatemala, met with faculty and students to discuss a program that supports indigenous education efforts of the Q'eqchi people.

\section{Restructured Syllabi}

Working with these experts in the field of global/international teacher education gave us the background knowledge with which to reexamine all credential course syllabi through the lens of our shared international goals. Examples of these changes in selected courses are highlighted below (italics added for emphasis):

- $\quad$ Multicultural and Philosophical Foundations in a Global Society: Issues related to the education of diverse learners in a global society will be explored.

- $\quad$ Psychological Foundations and Classroom Teaching Methods in U.S. and International Bilingual Classrooms: This course examines from a global perspective the theory and practice of socio-cultural and psychological aspects of development. 
- $\quad$ Elementary Curriculum Methods for Global Classrooms: Candidates learn to think critically about other cultures, international relations, and global environmental issues.

- Methods of Teaching Literacy and Language Arts: The course stresses the use of children's literature, including an international children's literature and global perspective, to promote reading and ways to create environments that support literacy development throughout the world.

\section{Comments from Our Graduates}

Finally, we examined survey data from our graduates to see whether or not these internationalization goals were actualized in K-12 classrooms. Program completers were surveyed to determine what, if anything, they remembered about internationalization/global assignments in the credential program and whether or not they incorporated some of these global goals into their own classrooms through readings, discussions, and/or activities. A survey went out to all individuals who graduated after the international reforms were put in place. They were asked to respond to the following: 1) Please share any memories that you have of your credential program's course readings/discussions/activities that were intended to increase your awareness of global/international/environmental issues and 2) Please share any specific activities that you have put in action in your classrooms with the goal of preparing your K-12 students for success in a globally connected society. We received responses from $29 \%$ of these credential completers. While $7 \%$ of the group indicated that they did not remember any such work in the credential program, many did. Below are examples of comments typically expressed by those in the latter group:

21 st century skills, globalization, how interconnected the world is with technology and communication

How to have pen pals in another country and how to connect with global classrooms

Reviewing and designing thematic units that incorporated environmental, international and global issues

Readings from all over the world to help us understand peoples and issues from around the world

Researched educational procedures in different countries by interviewing an individual from that country, then presented this research to the class

Discussing the global perspectives of education

Of that population of graduates who did remember learning about global issues in our teacher credential program, the following responses highlight some of the ways they now use this knowledge in their own classrooms to advance goals of internationalization:

During my time in the program, I designed an environmentally friendly curriculum for an assignment. The curriculum is global in scope and cross-curricular in nature. This will be my third year teaching it for Earth day!

The students love it and so do I.

Discovering project-based learning and expanding my students' education to encompass the global community beyond the classroom

Community outreach, literature units based on other nations

CNN Student news, Time for Kids "Around the World" Edition

I am currently wrapping up a unit on income, expenses, and budgets. This unit has helped my students understand finances and budgets of their own, but also how it is used worldwide. Students were introduced to money and currency in other countries. They were challenged to make monetary conversions as they would do so if they were to study abroad. While studying China, students were introduced to traditional Chinese music. We compared it to popular American classical and jazz music. 
Our school has become an integrated IPAD school; therefore, students are encouraged to read, research and analyze various works/issues/news from around the world.

Global awareness, with a balance on positively impacting local communities, is central to my teaching.

I have had students review current events (global events). I have had students read novels focused on other cultures.

Adopted an African classroom, connected with international Penpals, had discussions on Global perspectives and causes, and issues.

\section{CONCLUSION}

It would appear that the world is only going to get "flatter" in the years ahead as global and digital connections continue to move at the speed of light. Perhaps, as Ikeda (2005) states, "The key to the formation of global citizens is the educator, bearing out the concept that the teacher is the most important element in the educational environment". Are we, who are the teachers of teachers, no less critical to the actualization of these immensely important international reforms? Clearly, teacher educators must commit, and do it soon, to infusing global/international understanding into their programs as they instruct those who will educate the next generation of world citizens.

\section{AUTHOR INFORMATION}

Dr. C. Bobbi Hansen, is an Associate Professor at the University of San Diego where she teaches courses at both the preservice and graduate levels in Teacher Education. Her current research projects are in the areas of international science education and Project-based Learning (PBL), an approach to teaching in which students explore real-world problems and, in so doing, acquire $21^{\text {st }}$ Century skills. As a result of this work, she has been invited to present papers on PBL at multiple conferences in the past two years. She was just awarded a grant to develop and evaluate an innovative STEM strategy that uses place-based learning and 21st Century workplace skills for underrepresented high school students. E-mail: chansen@sandiego.edu

\section{REFERENCES}

1. Authors (2010). National Governors Association Center for Best Practices, Council of Chief State School Officers, Common Core State Standards, National Governors Association Center for Best Practices, Council of Chief State School Officers: Washington D.C.

2. Anderson, L.F. (1968) An examination of the structure and objectives of international education. Social Education. 35(7), 639-652.

3. Adams, J. \& Carfagna, A. (2006). Coming of age in a globalized world: The next generation. Bloomsfield, CT: Kumarian Press.

4. Becker, J.M. (1979). The world and the school: A case for world-centered education. In J. M. Becker, (Ed.), Schooling for a Global Age (pp. 33-57). New York: McGraw-Hill.

5. Biddle, D.S. (1996). Theory and practice in the development of curriculums in geography. In Gerber, R. and Lidstone. J. (Eds.) Developments and directions in geographical education. Philadelphia, PA: Channel View Publications.

6. Burbules, N., \& Torres, C. (Eds.). (2000). Globalization and education: Critical perspectives. New York: Routledge.

7. Calleja, J. (Ed.) (1995). International education and the university. Paris, France: UNESCO.

8. Davies, L. (2006). Global citizenship: Abstraction or framework for action? Educational Review, 58, 5-25.

9. Diaz, C., Massialas, B, \& Xanthopoulos, J. (1999). Global perspectives for educators. Boston, MA: Allyn and Bacon.

10. Friedman, T.H. (2005). The world is flat. New York: Farrar, Straus and Giroux.

11. Fuller, T. (1998). American education in a global society: Internationalizing teacher education. White Plains, NY: Longman. 
12. Gragert, E. (2009). Partners in success: Creating international education collaborations. Educational Update. 51(8).

13. Gutek, G.L. (1993). American education in a global society: Internationalising teacher education, New York: Longman.

14. Hammond, Linda-Darling (2010). The flat world of education: how America's commitment to equity will determine our future (multicultural education). New York, NY: Economic Institute and Teachers College.

15. Hanvey, R. G. (1976). An attainable global perspective. Denver, CO: The Center for Teaching International Relations, The University of Denver.

16. Ikeda, D. (2005). In Educating citizens for global awareness, ed, N. Noddings, xi. New York: Teachers College Press.

17. Merryfield, M. (2002). The difference a global educator can make. Educational Leadership. 60(2). 18-21.

18. Merryfield, M., Lo, J., Po, S. \& Kasai, M. (2008). World-mindedness: Taking off the blinders. Journal of Curriculum and Instruction, 2(1), 6-20.

19. Metzler, John M. 1998. "Challenges for Title VI programs of outreach in foreign language and international studies." John N. Hawkins, Carlos Manuel Haro, Miriam A. Kazanjian, Gilbert W. Merkx, and David Wiley, eds. International Education in the New Global Era: Proceedings of a National Policy Conference on the Higher Education Act, Title VI, and Fulbright-Hays Programs. Los Angeles: University of California Press: 117-131.

20. Noddings, N. (Ed.). (2005). Educating citizens for global awareness. New York: Teachers College Press.

21. Nordgren, R. D. (2002). Globalization and education: What students will need to know and be able to do in the global village. Phi Delta Kappan, 84, 318-321.

22. Shorr, Howard. (2006). Teaching history: Why multiculturalism is so important. History News Network. 30(02). Retrieved, May 13, 2010 from http://hnn.us/articles/20461.html

23. Skelton, M. (2004). Education for educational mindedness, Conference Proceedings, Retrieved, May 23, 2010 from http://www.intedalliance.org/page.cfm?p=31

24. Tye, K. (Ed.) (1991) Global education: From thought to action. Alexandria, VA: Association for Supervision and Curriculum Development. 